\title{
Truck Driver Dies after being Run Over by Propane Transport Rolling Backward at Bulk Plant
}
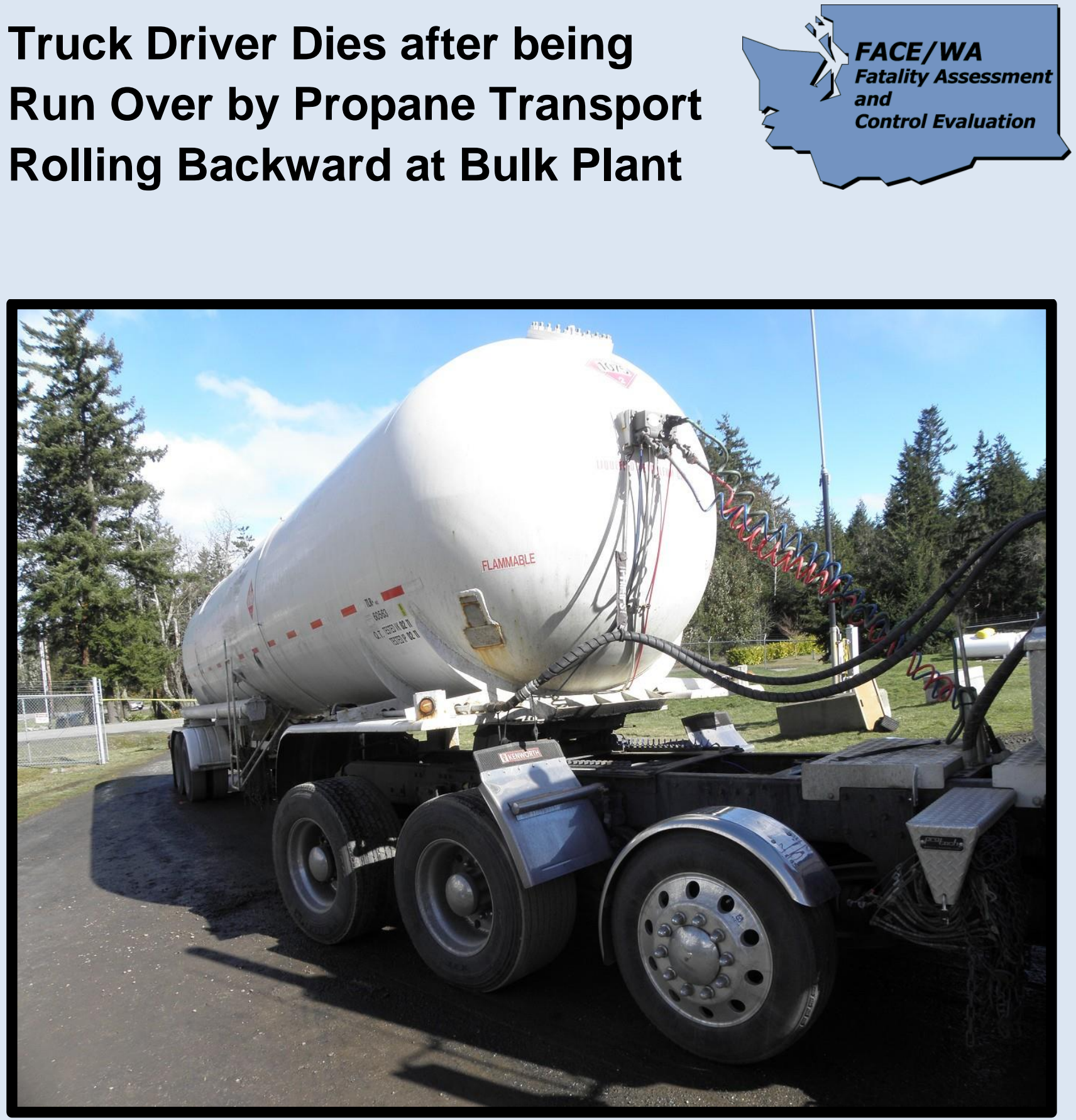

Investigation: \# 11WA013

Release Date: May 21, 2013

SHARP Report: \# 52-28-2013 
TABLE OF CONTENTS

CONTENTS

PAGE

SUMMARY

3

RECOMMENDATIONS

4

INTRODUCTION

$\begin{array}{ll}\text { Employer } & 5\end{array}$

Employer Safety Program and Training 5

Victim 6

$\begin{array}{ll}\text { Equipment } & 6\end{array}$

$\begin{array}{ll}\text { Incident Scene } & 7\end{array}$

$\begin{array}{ll}\text { Weather } & 8\end{array}$

$\begin{array}{lr}\text { INVESTIGATION } & 8\end{array}$

$\begin{array}{lr}\text { CAUSE OF DEATH } & 14\end{array}$

$\begin{array}{lr}\text { CONTRIBUTING FACTORS } & 14\end{array}$

$\begin{array}{ll}\text { RECOMMENDATIONS AND DISCUSSION } & 15\end{array}$

$\begin{array}{lr}\text { REFERENCES } & 17\end{array}$

$\begin{array}{lr}\text { INVESTIGATOR INFORMATION } & 18\end{array}$

$\begin{array}{lr}\text { FACE PROGRAM INFORMATION } & 18\end{array}$

$\begin{array}{lr}\text { ACKNOWLEDGEMENTS } & 19\end{array}$ 


\section{SUMMARY}

In March of 2011, a 69-year-old propane transport driver died when his loaded cargo tank transport semi-trailer truck rolled backward and over him. The driver was employed by a farm supply cooperative which delivers bulk propane in cargo tank semi-trailer trucks, also known as propane transports.

On the day of the incident, the driver arrived to make a fuel delivery at a bulk plant facility. Upon hooking up the cargo tank hoses to the facility's fuel unloading bulkhead and starting to dispense fuel, he discovered that the transfer pump was leaking externally. This condition would prevent safe delivery of the fuel. The driver used his cell phone to contact his supervisor through his dispatcher at 6:21 p.m. to alert him of the situation. The supervisor told the driver he would need to take the transport to another city for repairs the following day and that he would make arrangements and then call him back with details. The supervisor attempted to call the driver numerous times, but could not make contact with him.

At 7:44 a.m. the next morning a representative of the bulk plant facility arrived at the yard where he found the driver lying deceased underneath the semi-tractor's right rear wheel. He contacted emergency services and a deputy sheriff and fire and rescue personnel arrived at the scene.

Upon examination of the incident scene by the first responders they noted that 1) the vehicle's engine was running and headlights on, 2) the brake for the cargo tank transport semitrailer was set, 3) the tractor's brake was not engaged, and 4) no wheel chocks were visible. Apparently, the driver had attempted to drive away, but was unable to because the trailer's brakes were still engaged by the air brake safety interlock system. When a metal hinged gate located on the trailer's undercarriage in front of the fuel loading and unloading connections is opened, an air valve is activated which engages the trailer's brakes. In order for the vehicle to be driven this gate must be closed. (This system is designed to prevent a driver from driving away while hoses are connected to the fuel loading/unloading bulkhead.)

To close the brake interlock gate the driver exited the cab and walked around to the trailer's right side. He did not engage the parking brake (handbrake) in the cab. When he closed the safety interlock gate on the trailer, the brakes which had been holding the vehicle were released, thereby allowing it to roll backward down the dirt driveway. He ran alongside the trailer to open the gate again, so as to stop the truck. He succeeded in opening the gate, which engaged the brakes, but as he did so he either slipped or was struck by a structural member of the semitrailer and fell down and was run over by a wheel on the semi-tractor. 


\section{RECOMMENDATIONS}

To prevent similar occurrences in the future, the Washington State Fatality Assessment and Control Evaluation (FACE) investigation team recommends employers of propane transport truck drivers follow these guidelines during fuel loading and unloading operations at bulk plants:

- Create, implement, and enforce written policies to ensure that propane transports will not be allowed to roll away when the driver is outside the cab. These policies should include procedures requiring drivers to 1) set the vehicle's parking brake before leaving the cab; 2) use wheel chocks; 3) never attempt to stop a rolling vehicle from outside the cab; and 4) perform a vehicle pre-departure inspection.

- Train drivers to recognize the hazard of vehicle rollaway due to improper vehicle securement when parked and to use safe work practices to prevent unintended vehicle movement.

Additionally, vehicle designers and manufacturers should:

- Consider creating safety systems to either alert or prevent the vehicle operator from releasing the trailer parking brake at the brake interlock gate without first manually setting the parking brake from the cab. Alternatively, an alarm could be created to sound-off when the driver's door is opened and the parking brake has not been manually engaged. 


\section{INTRODUCTION}

In March of 2011, the Washington State FACE Program was notified by the Washington State Department of Labor and Industries' Division of Occupational Safety and Health (DOSH) of the death of a 69-year-old male propane transport driver. The driver died from injuries he received when his semi-trailer truck rolled backward and he was pinned under a wheel of the semi-tractor. In April of 2012, Washington State FACE investigators traveled to the company's office to interview the energy division manager who also is the safety officer for the energy and agronomy divisions of the company. During the course of the investigation documents reviewed included the victim's death certificate and DOSH investigation file.

\section{Employer}

The employer is a member-owned farm supply cooperative. Started in 1982, the cooperative has three divisions: a retail division which sells a variety of products through several "country stores," an agronomy division which sells fertilizer, seeds, chemicals, and other agricultural products, and an energy division which sells both retail and wholesale petroleum products, including propane, throughout two northwest states. The business has more than 100 employees, including 4 fuel delivery drivers. There is seasonal fluctuation in customer demand for propane, with the busy season occurring from September to March.

\section{Employer Safety Program and Training}

In accordance with Washington State law, ${ }^{1}$ the employer has a formal, written accident prevention program (APP). They have a contract safety consultant who acts as an overall safety coordinator.

The energy division manager, who also serves as the safety officer for the energy and agronomy divisions, holds safety meetings with the transport drivers monthly. These meetings are generally conducted primarily by email and sometimes by phone, as driver's schedules make it difficult to meet as a group. Twice a year they gather for an all-hands safety meeting.

The employer has a policy requiring the use of wheel chocks whenever transports are parked.

At the time of the incident, the employer expected drivers to follow the company policy of using wheel chocks, but did not monitor the use of wheel chocks by drivers. Postincident, the company safety officer periodically checks on drivers who are at customer locations delivering fuel to ensure that they are using wheel chocks and to observe their safety behaviors. 


\section{Victim}

The victim (hereafter referred to as the "driver") was a 69-year-old male bulk propane transport driver. He had a valid class "A" Washington State commercial driver's license $(\mathrm{CDL})$ with endorsements for driving a liquid bulk cargo tank motor vehicle with double/triple trailers transporting hazardous material. His driver's license had a restriction requiring him to wear corrective lenses. He had driven trucks for most of his working life.

According to the employer, he was a seasonal employee working on an as needed basis from September to March. This was his third season with this employer. Previously he had hauled propane for about 12 years for another company and had spent many years as a log truck driver.

His training included hazardous materials transportation training, as required by Federal law, ${ }^{2}$ and the Propane Education and Research Council's Certified Employee Training Program. ${ }^{3}$

He had made numerous customer fuel deliveries to the incident site yard, both for this employer and a previous employer. His last delivery to this customer was ten days prior to the incident.

\section{Equipment}

The vehicle involved in the incident was a 2006 four-axle Kenworth truck-tractor in combination with a 1965 double-axle Lubbock MC330 cargo tank transport semitrailer (see photo 1). The MC 330 cargo tank is the U.S. Department of Transportation designation for a high pressure cargo tank built before December 1, 1967 for the transport of compressed gasses. In the propane industry, a vehicle with a tractor and cargo tank trailer combination, is known as a propane transport. ${ }^{4,5}$ The U.S. Department of Transportation designates this type of vehicle a cargo tank motor vehicle. ${ }^{6}$ The cargo tank, with a 10,600 gallon capacity, was laden with 8,940 gallons of liquefied petroleum gas (LPG), also known as propane. The total loaded weight of the transport vehicle was 79,900 lbs. 


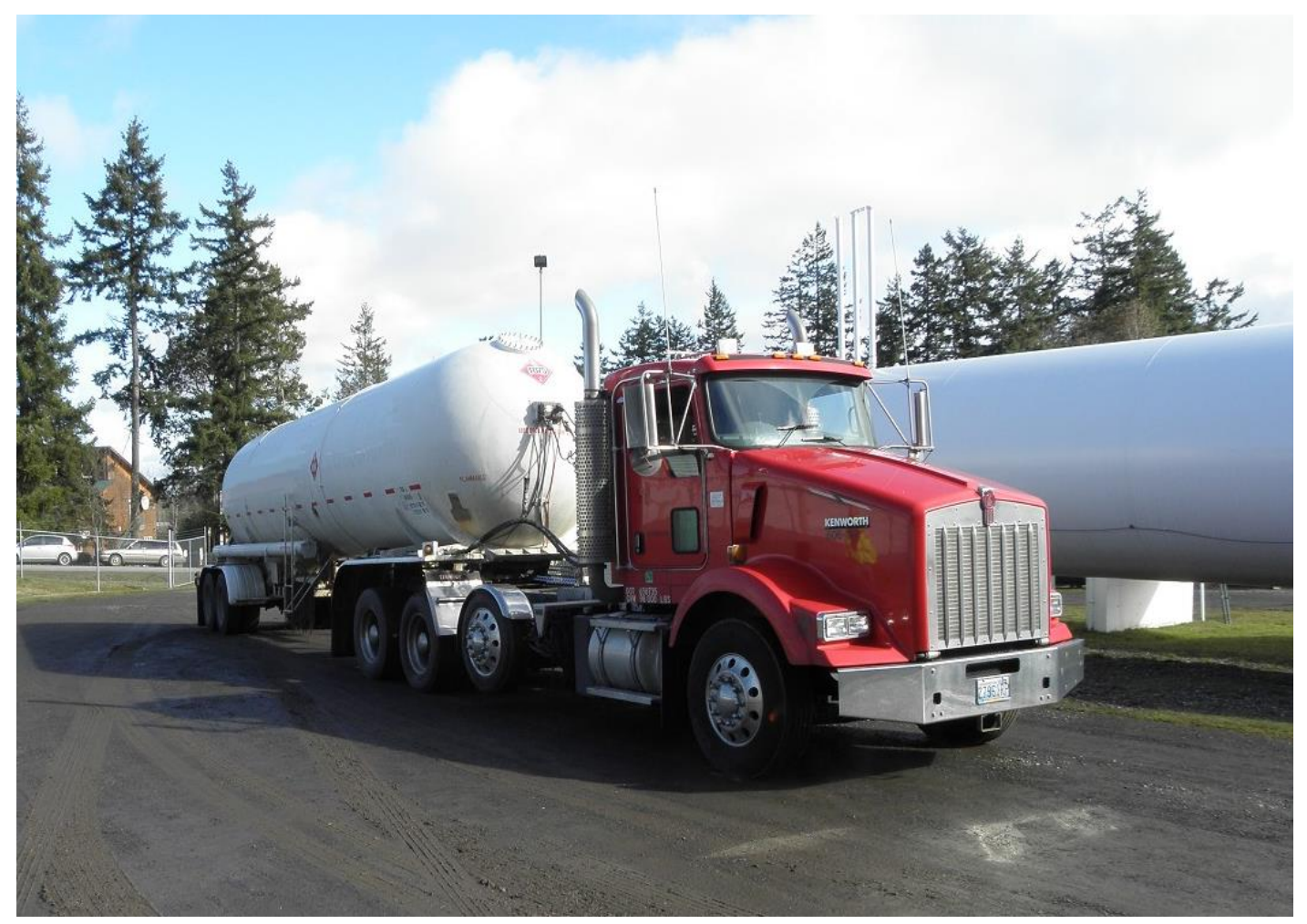

Photo 1. Propane transport at bulk plant incident scene.

\section{Incident Scene}

The location of the incident was a bulk plant facility consisting of propane storage tanks in a yard in Western Washington (see photos 1 and 2). The owner of the facility is a retail seller of propane. The surface of the yard and its driveway were composed of soft, wet dirt and gravel. The surface area where the victim parked his transport to deliver the fuel had a down-slope of 1 to 2 degrees with the driveway area behind the transport sloping down a further 2 to 3 degrees. There was no one other than the driver present at the time of the incident. 


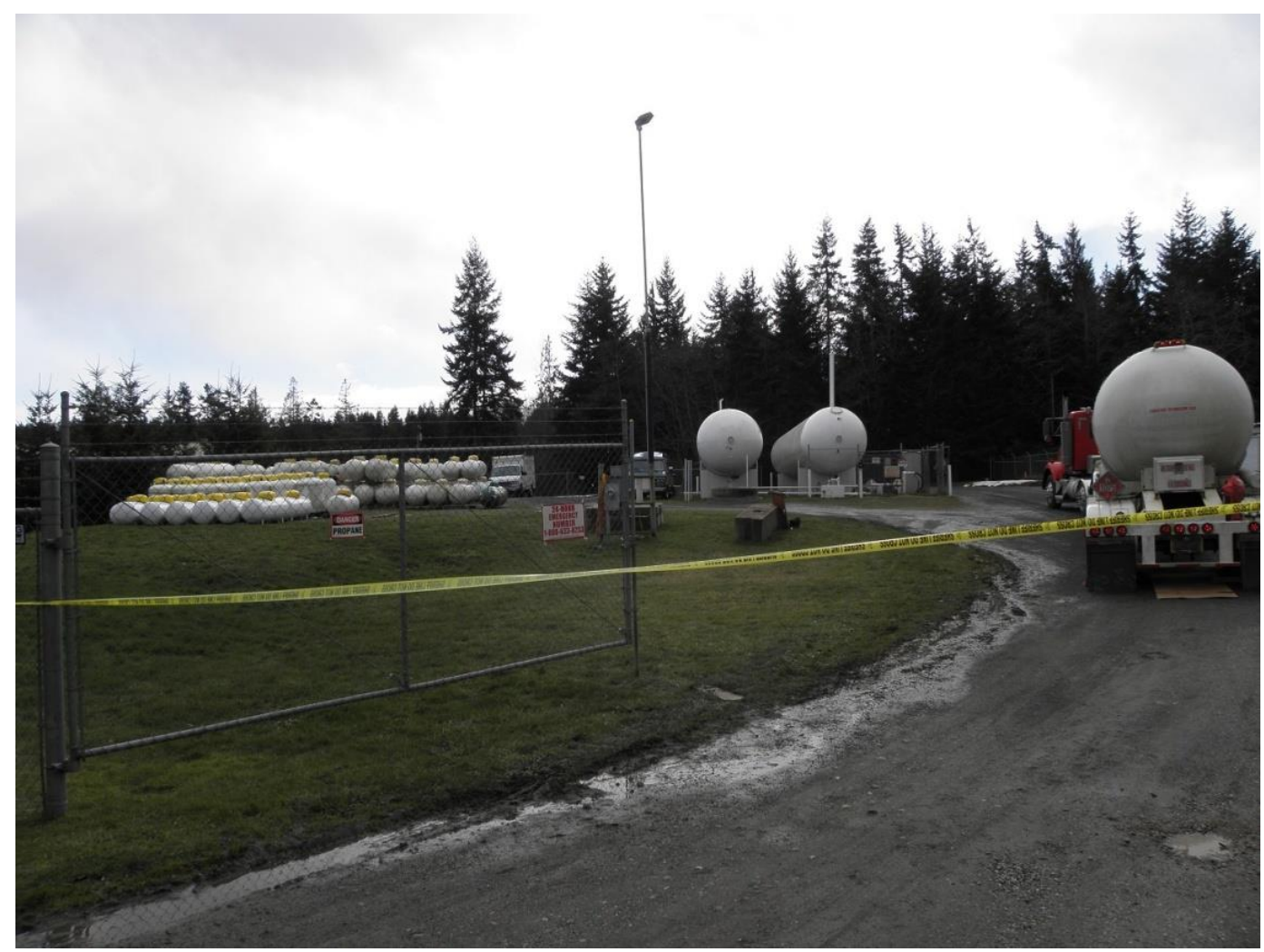

Photo 2. Propane bulk plant facility. Incident propane transport on far right.

\section{Weather}

Although the precise time the incident occurred is unknown, most likely it occurred around 6:30 p.m. or sometime shortly thereafter. It was raining lightly at 6 p.m. and had been doing so for approximately the past three hours. The temperature was 39.9 degrees Fahrenheit with a wind blowing from the east at $9.2 \mathrm{mph}$. The day's total precipitation amounted to 0.01 inch. $^{7}$

\section{INVESTIGATION}

In March of 2011, the driver was assigned by his employer to make a fuel delivery. The driver started his working day at about noon when he arrived at the employer's premises. He proceeded to perform a vehicle pre-trip safety check, have the cargo tank loaded with fuel, and then departed to drive to the customer delivery site several hours away in another part of the state. At approximately 5 p.m., he drove his propane transport into the customer's bulk propane storage yard. He was to make a delivery of 8,940 gallons of LPG. He was working solo; there was no one else present at the yard. 
In order to dispense the fuel to the customer's bulk storage tank, the driver would have had to hook up the cargo tank hoses to the facility's fuel unloading bulkhead. The configuration of this trailer allowed for fuel to be dispensed from valve connections located on either its right front or left front sides. On this occasion, the driver positioned the transport so that fuel could be dispensed from the left front of the cargo tank trailer. Hoses are stored on the left front side of the cargo tank trailer and consist of the vapor pressure equalizing hose and the delivery hose assembly.

He would have then walked around to the right side of the trailer to open a metal hinged gate. This gate, which is in front of a set of loading and unloading valve connections in the trailer's undercarriage, is variously known as a loading, safety, safety interlock, brake interlock, or Dixie gate (see photos 3 and 4). In order to dispense fuel this gate must be opened to the "down" position. To open the gate a pin must be removed. When the gate is opened an air interlock valve is activated, which sets the trailer's parking brakes. This gate which activates the interlock operating air valve is located on the right side of the trailer only.

The driver cannot drive the vehicle as long as the brake interlock gate is open and the interlock operating air valve is activated. This safety air brake interlock system is an optional feature on propane transport trailers. The purpose of the safety air brake interlock system is to prevent the truck driver from driving away while hoses are not properly stored for travel or are connected to a fuel loading or unloading bulkhead, or the vehicle's power take off (PTO), which provides power to the fuel transfer pump's main shaft, is engaged. When this gate is in the closed or "up" position the trailer's parking brakes are released and the truck may be driven.

The safety air brake interlock system when activated locks the transport trailer brakes. The vehicle cannot be driven unless the safety gate is closed, thereby releasing the trailer brakes. 


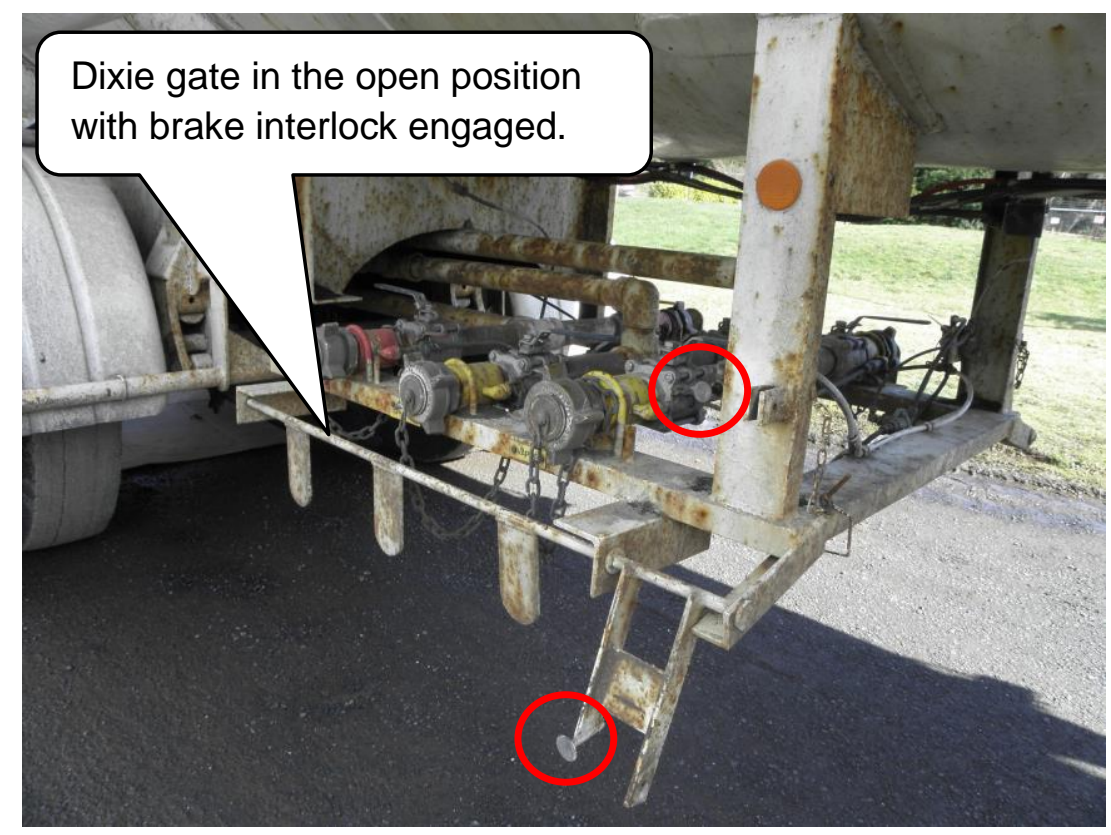

Photo 3. Fuel loading/unloading valve connections with trailer brake interlock or Dixie gate on the trailer undercarriage. The gate is in the open or "down" position which sets the trailer brakes. The interlock operating air valve connection is the metal button circled in the right center of the photo; located beneath it and circled is the piece of metal that when the gate is up will depress the air valve.

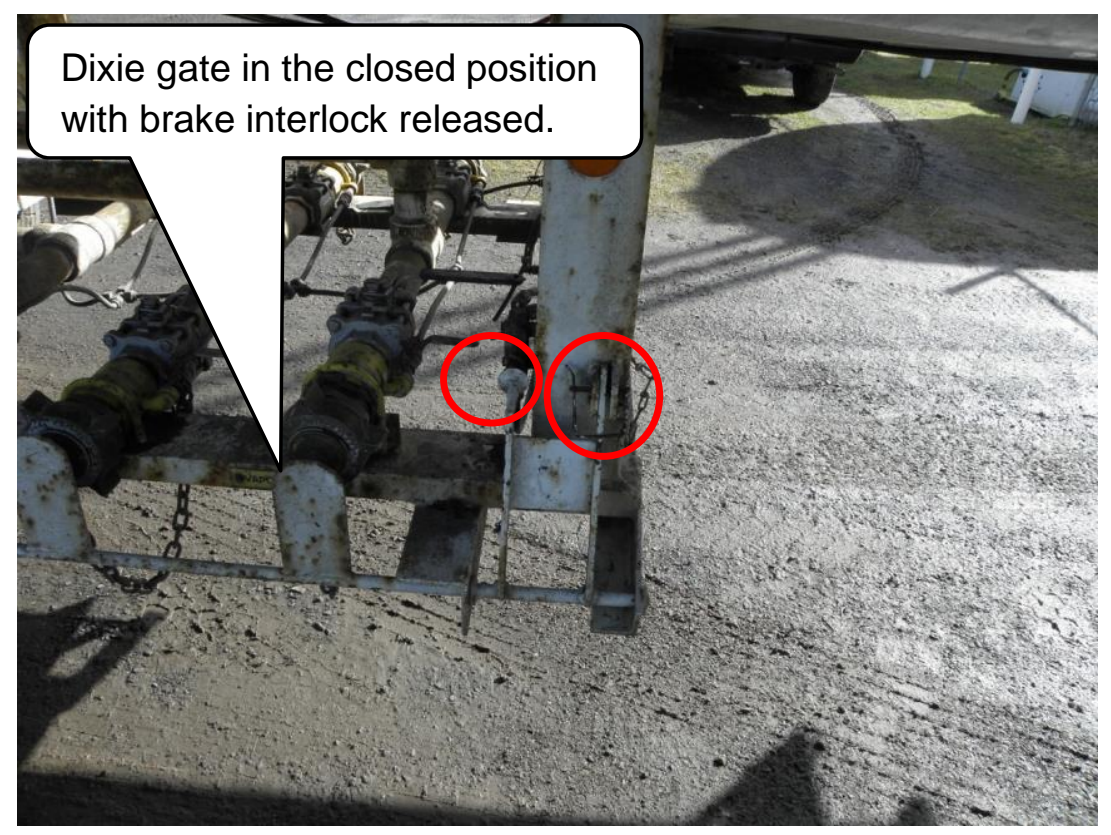

Photo 4. The trailer brake interlock or Dixie gate in the closed or "up" position which releases the trailer brakes and allows the vehicle to be driven. The metal pin circled in the right of the photo keeps the gate in place; to the left of the pin is the piece of metal attached to the gate and is depressing the air valve. 
Once the driver opened the brake interlock gate he would have had to apply pressure to the trailer brake system to allow the internal propane delivery valves to open through the passive emergency shutdown system, thus making it possible to transfer propane from the semitrailer tank to the customer's bulk tank.

The driver then began the transfer of propane from the cargo tank to the bulk storage tank. As he was doing so, he noticed that the PTO driven transfer pump was leaking externally. As a leak of this nature presents an explosion hazard, he stopped the fuel delivery. (A subsequent incident investigation by DOSH determined that the transfer pump seal had failed.)

According to the driver's supervisor, the energy division manager, the driver used his cell phone to contact the company dispatcher to let her know what had happened. The driver then made phone contact with his supervisor, who was out of the office in another part of the state. After discussing the situation, the supervisor told the driver that due to the unsafe condition of the fuel pump the driver needed to take the rig to another city to have the fuel pump repaired. As the repair could not be made until the following day, the driver would have to stay overnight in a motel. The supervisor told the driver he would make arrangements for the repair and would call him back to let him know the details.

After the supervisor had phoned a repair shop and made arrangements, he called the driver. The driver did not answer his phone. The supervisor knew that cell phone coverage could be unreliable in the area where the driver was located. He made numerous more calls to the driver during the course of the evening, including waking up a couple of times during the night to call; but the driver never answered his phone. The supervisor decided that because of bad cell phone reception or that his phone battery charge was low he could not reach the driver and that, as the driver was familiar with the area, he had checked into a motel, turned off his cell phone, and gone to sleep.

At 7:44 a.m. the following morning the co-owner of the company that operated the bulk plant facility arrived at the yard to find the driver's body lying underneath the semitractor's right rear tire. He called the county sheriff's office and a deputy arrived at the scene within minutes. The sheriff's deputy surveyed the scene and noted that the truck's engine was running and its headlights were on. Shortly thereafter members of the local fire and rescue department arrived on the scene. One of their personnel entered the truck's cab, and observed that the brake for the cargo tank transport semitrailer was set, but that the tractor's parking brake was not engaged. A sheriff's deputy observed that the wheel chocks were in the equipment box behind the cab and appeared clean and unused. The county deputy coroner arrived on scene and declared the victim deceased. 
A fire and rescue officer contacted the victim's employer and spoke with their dispatcher. She stated that she had last spoken with the driver at about 6:21 p.m. the previous evening. The driver's cell phone indicated that he had missed phone calls from approximately 6:30 p.m. onwards.

As the incident was unobserved, the precise sequence of events leading to the victim's death is unable to be determined. However, based on the evidence of the incident scene and accounts of incident responders and company employees, the following scenario seems probable:

After speaking with the company dispatcher and his supervisor the driver decides to depart the bulk fuel plant and drive to a motel where he will stay for the evening before bringing the transport in for repairs in the morning. He stows the fuel delivery hoses in preparation for departure either before making his phone calls or after.

Upon getting into the truck's cab he releases the parking brake, and attempts to drive away, but could not do so as the trailer's brakes were still engaged by the brake interlock because the brake interlock gate was open. Stepping out of the cab without setting the tractor's parking brake he leaves the engine running, does not use wheel chocks, and walks around to the right side of the cargo tank semi-trailer where the brake interlock gate is located and closes the gate by swinging it up. He inserts a metal pin to keep it in place so that it will not open during transport. The closing of the brake interlock gate depresses a button which releases the trailer's brakes.

With no brakes engaged the transport starts to roll backward. He runs after the rolling vehicle, reaches under the cargo tank, gets the brake interlock gate pin out and opens the gate in order to activate the trailer brake and stop the vehicle. The momentum of the loaded vehicle rolling downhill and the fact that the air brake takes between $11 / 2$ to 3 seconds to engage prevents it from stopping immediately. As the vehicle rolls, he is struck by the cargo tank ladder or a structural member of the tank or semi-trailer and is knocked to the ground, or slips/trips and falls on wet dirt. The right rear wheel of the semi-tractor rolls onto his right leg and lower abdomen/pelvic area, and traps him beneath the wheel as the vehicle comes to rest (see photo 5).

The propane transport had rolled backward down the 3 to 5 degree downgrade dirt driveway before stopping approximately 70 feet from where it had been parked (see figure 1 and photo 6 ). 


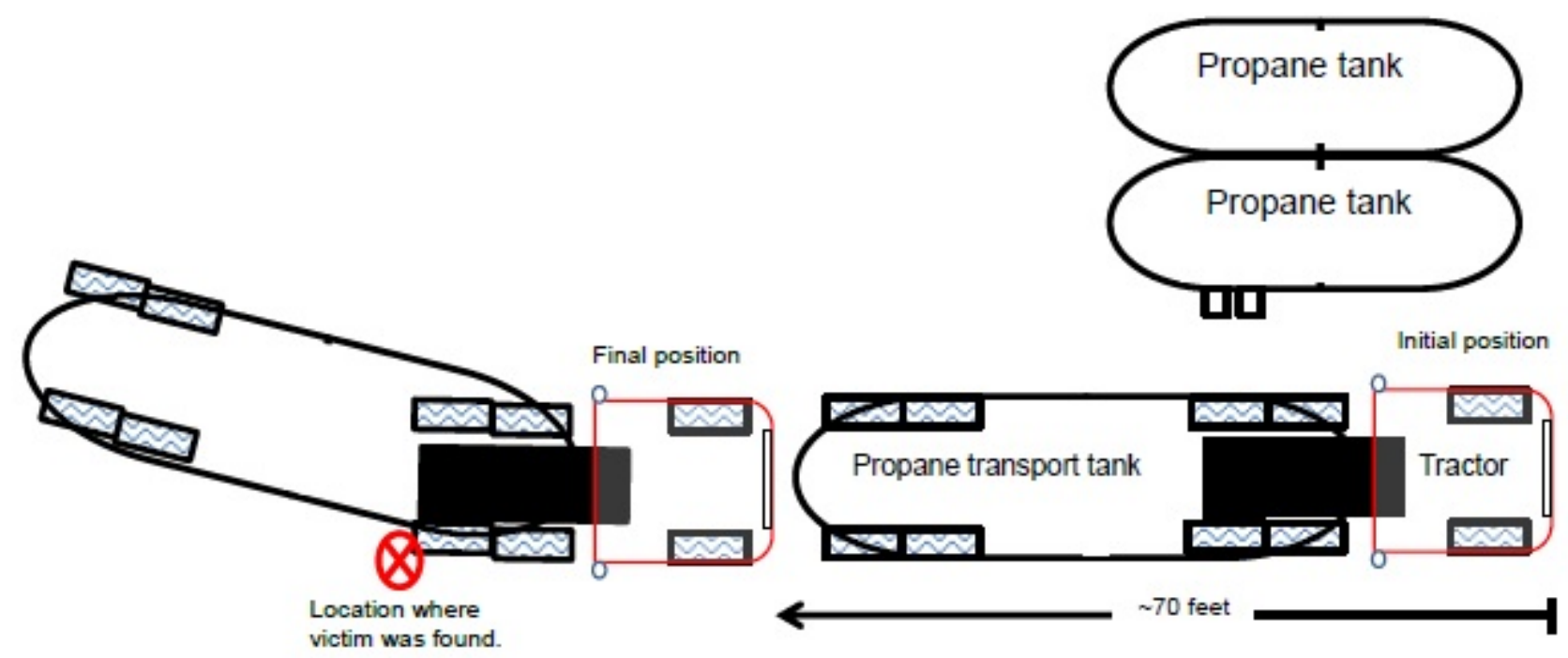

"Not drawn to scale.

Figure 1. Illustration of incident scene showing initial and final position of the propane transport relative to the location of the stationary propane tanks and the location where the victim was found.

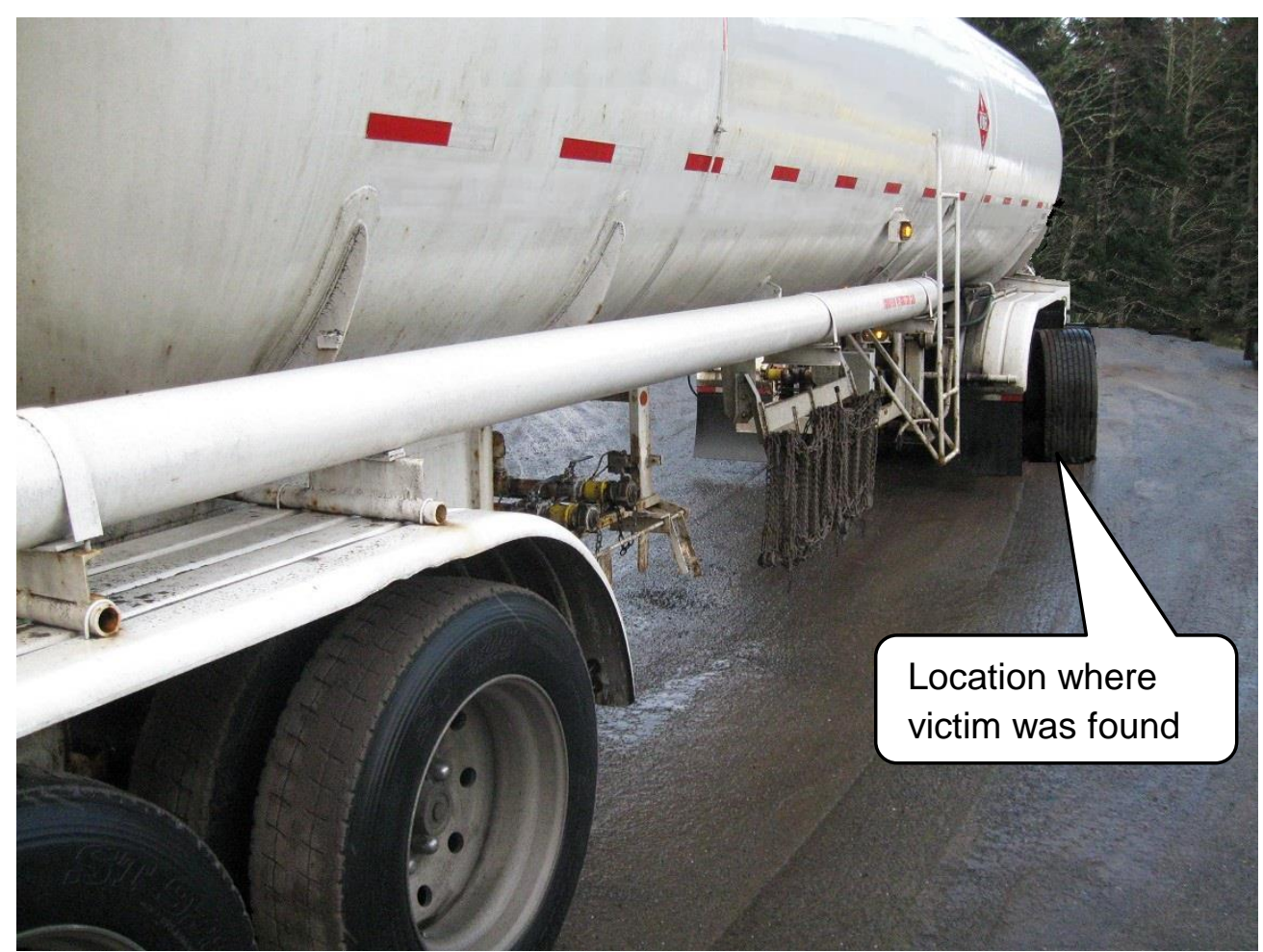

Photo 5. Incident scene with propane transport trailer. Victim was found under the semitractor wheel in the upper right. 


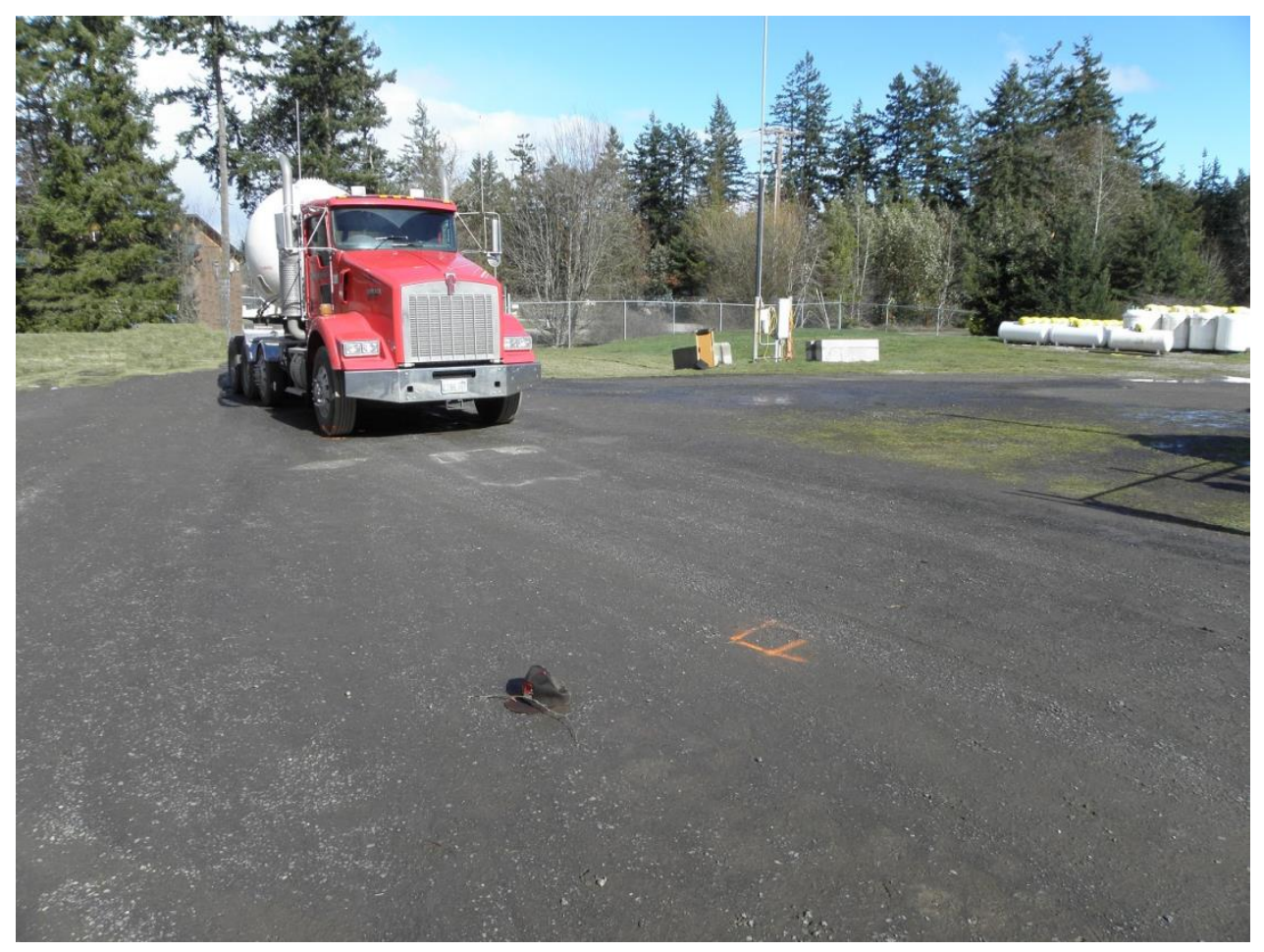

Photo 6. Incident scene showing where the transport came to rest after rolling approximately $\mathbf{7 0}$ feet backward. In the foreground is the victim's cap where first responders found it.

\section{CAUSE OF DEATH}

The medical examiner listed the cause of death as traumatic asphyxiation due to or as a consequence of blunt force injuries of lower trunk and extremity due to or as a consequence of being backed over by tractor-trailer rig.

\section{CONTRIBUTING FACTORS}

Occupational injuries and fatalities are often the result of one or more contributing factors or key events in a larger sequence of events that ultimately result in the injury or fatality. Washington FACE investigators identified the following factors that may have contributed to the driver being run over by his unattended propane transport semitrailer truck:

- Failure to set the vehicle's parking brake before exiting the cab.

- Failure to use wheel chocks.

- Attempting to stop a vehicle as it rolled downhill. 


\section{RECOMMENDATIONS AND DISCUSSION}

Recommendation \#1: Create, implement, and enforce written policies to ensure that propane transports will not be allowed to roll away when the driver is outside the cab. These policies should include procedures requiring drivers to 1) set the vehicle's parking brake before leaving the cab; 2) use wheel chocks; 3) never attempt to stop a rolling vehicle from outside the cab; and 4) perform a vehicle pre-departure inspection.

Discussion: Employer policies should emphasize to their transport drivers the importance of following these procedures during fuel loading and unloading to prevent a vehicle rollaway:

1) Set the vehicle's parking brake before leaving the cab. Never exit the vehicle without engaging the parking brake.

2) Use wheel chocks.

Once the parking brake is set the driver should exit the parked vehicle and place wheel chocks against the front and back of one of the rear semi-tractor wheels on both sides of the truck. ${ }^{8,9}$ Select and use chocks manufactured for the type and size of vehicle tire to be chocked. Do not use dunnage, blocks of wood, stones, or other objects not manufactured to serves as chocks. Employers should create and enforce a wheel chocking policy for all fuel loading and unloading operations. Even if there visually does not appear to be a slope where the vehicle is parked, even a small slope can be sufficient to allow a vehicle to roll if no braking systems are operative. It appears that in this incident the driver did not use his wheel chocks, as they were found clean in the equipment box in the vehicle's cab. If the driver had used the chocks, he would have needed to remove them before driving away; presumably, this would be the last thing he would need to do before entering the vehicle cab and departing. While gathering the chocks he would have, depending on whether he walked around the front or rear of the vehicle, needed to either walk by or near the safety interlock gate, where he could have noticed that the gate was still open.

3) Never attempt to stop a rolling vehicle from outside the cab.

The risk of injury or death is great when attempting to stop a moving vehicle from outside the cab. Attempting to reenter the cab or, as in this case, unpinning the safety gate to activate the trailer brake interlock, as a vehicle rolls downhill, exposes the driver to the hazards of being struck by the truck or trailer, or its parts, or being run over by the vehicle's wheels.

4) Perform a vehicle pre-departure inspection. 
After fuel loading or unloading is completed the driver should walk around the transport and perform a pre-departure inspection. This inspection should include making sure that the vehicle is secured against unintended movement by ensuring that the tractor parking brake has been manually set from the cab, the trailer brake interlock gate is closed and in the travel position, and the wheel chocks have been removed and stowed.

Employers should make periodic checks of their drivers to ensure that established safe working procedures are being followed.

In this incident, the driver encountered an upset condition while attempting to deliver fuel and may have been understandably frustrated and thrown off - his routine was broken. It is important that drivers adhere to their standard operating procedures, even when things go wrong.

Recommendation \#2: Train drivers when parking a transport to recognize the hazard of vehicle rollaway due to improper vehicle securement and to use safe work practices to prevent unintended vehicle movement.

Discussion: Employers should train their transport drivers in hazard recognition and their established safety policies and procedures when they are hired and give periodic refresher trainings. Employers should observe and assess drivers' competencies to perform the required procedures safely.

Recommendation \#3: To prevent a transport vehicle from rolling away, designers and manufacturers should consider creating safety systems to either alert or prevent the vehicle operator from releasing the trailer parking brake at the brake interlock gate without first manually setting the parking brake from the cab. Alternatively, an alarm could be created to sound off when the driver's door is opened and the parking brake has not been manually engaged.

Discussion: The brake safety interlock system used in the incident cargo tanker was designed to prevent a vehicle drive-away. What happened in this incident was the driver failed to set the semi-tractor parking brake before exiting the vehicle's cab and then walked back to the safety interlock gate which he then closed. This deactivated the trailer brakes leaving the transport without brakes, allowing it to roll backward down a slope. 
In order to prevent an incident such as this, where a vehicle without the parking brake engaged rolls away, perhaps a safety interlock could be created to prevent the driver from performing an unsafe action. Alternatively, a warning signal could be created to alert the driver that the parking brake needs to be set. For example, an in-cab alarm could be created to sound when the driver opens the cab door without manually setting the parking brake. ${ }^{9}$ While further innovation is possible, parking brake/handbrake warning alarms ${ }^{10-14}$ and vehicle anti-rollaway braking systems ${ }^{15}$ are commercially available.

\section{REFERENCES}

1. Washington State Department of Labor and Industries, Accident Prevention Program. http://www.Ini.wa.gov/Safety/Basics/Programs/Accident/default.htm

2. U.S. Code of Federal Regulations, Title 49 Transportation, Part 172, Subpart H - Training. http://www.ecfr.gov/cgi-bin/textidx?c=ecfr\&SID =51f679ee8da331aec642c1 $\mathrm{cb} 5791 \mathrm{c} 460 \& \mathrm{rgn}=$ div6\&view=text\& node $=49: 2 \cdot 1 \cdot 1 \cdot 3 \cdot 8 \cdot 8 \& i d n o=49$

3. Propane Education and Research Council, Certified Employee Training Program. http://www.propanesafety.com/workforce-training-programs/certifiedemployee-training-program/about-certification/

4. Propane Education and Research Council. http://www.propanesafety.com/

5. National Propane Gas Association. http://www.npga.org/i4a/pages/index.cfm?pageid=1

6. U.S. Code of Federal Regulations, Title 49 - Transportation, Part 178.320, Subpart J - Specifications for Containers for Motor Vehicle Transportation http://www.ecfr.gov/cgi-bin/textidx?c=ecfr\&SID=d4bb2b27a39e441640b5f1a1ab7e3749\&rgn=div8\&view=text\& node $=49: 3 \cdot 1 \cdot 1 \cdot 1 \cdot 1 \cdot 7 \cdot 1 \cdot 5 \&$ idno $=49$

7. Weather Underground. http://www.wunderground.com/history/airport/KNUW/2011/3/1/DailyHistory.html

8. Washington Administrative Code (WAC) 296-865-30015 http://www.Ini.wa.gov/WISHA/Rules/motorvehicles/HTML/296-865300.htm\#30015

9. Fatality Assessment and Control Evaluation, National Institute for Occupational Safety and Health. Delivery Truck Driver Dies after being Crushed by a Truck while Making a Delivery to a Local Market. http://www.cdc.gov/niosh/face/stateface/ca/94ca007.html

10. Safety Brake Set Inc. http://www.safetybrake.com/02.html

11. O.W.L. Vehicle Electronic Systems Ltd. http://www.safervehicles.co.uk/handbrake\%20warning.html

12. GSL Electronics. http://www.gsl.com.au/alarms-and-disconnects-hand-brakealarm.html 
13. Maple Fleet Services. http://www.maplefleetservices.co.uk/cat/detail/21-driverassist-a-reversing-aids/flypage/112-handbrake-warning-alarm.html?sef=hcfp

14. Redarc Electronics. http://www.redarc.com.au/products/product/handbrakealarm/

15. HTK Engineering LLC. http://www.htkengineering.com/HTKwebsite 20130123/

\section{Investigator Information}

Todd Schoonover has a PhD in Industrial Hygiene from the University of Illinois at Chicago. He is a Certified Industrial Hygienist $(\mathrm{CIH})$ and Certified Safety Professional (CSP). Todd is currently the Principle Investigator for the WA FACE Program.

Eric Jalonen has a Master of Public Health (MPH) degree from East Carolina University. He is a Research Investigator with the WA FACE Program

Randy Clark has a BA from the Evergreen State College. He is a Research Analyst with the WA FACE Program.

\section{Washington State FACE Program Information}

The Washington State Fatality Assessment and Control (WA FACE) program is one of many workplace health and safety programs administered by the Washington State Department of Labor \& Industries' Safety \& Health \& Research for Prevention (SHARP) program. It is a research program designed to identify and study fatal occupational injuries. Under a cooperative agreement with the National Institute for Occupational Safety and Health (NIOSH), WA FACE collects information on occupational fatalities in WA State and targets specific types of fatalities for evaluation. WA FACE investigators evaluate information from multiple sources. Findings are summarized in narrative reports that include recommendations for preventing similar events in the future. These recommendations are distributed to employers, workers, and other organizations interested in promoting workplace safety. NIOSH-funded, state-based FACE programs include: California, lowa, Kentucky, Massachusetts, Michigan, New Jersey, New York, Oregon, and Washington. WA FACE does not determine fault or legal liability associated with a fatal incident. Names of employers, victims and/or witnesses are not included in written investigative reports or other databases to protect the confidentiality of those who voluntarily participate in the program.

Additional information regarding the WA FACE program can be obtained from:

Washington State FACE Program

www.Ini.wa.gov/Safety/Research/FACE/default.asp

PO Box 44330

Olympia, WA 98504-4330

1-888-667-4277 


\section{ACKNOWLEDGMENTS}

This report was reviewed by stakeholders from labor and business communities and various Washington State and Federal worker safety agencies. Though we are unable to acknowledge specific individuals for their contributions to this report, we would like to recognize the following for their help and support of the FACE mission and objectives:

- The employer's representative

- Division of Occupational Safety and Health (DOSH)

- Federal FACE Program Management (NIOSH)

- Safety \& Health Assessment \& Research for Prevention (SHARP) 